\title{
Penerapan Automatic Disinfection Chamber Untuk Pencegahan Covid19 di Pondok Pesantren Al Mujaddadiyah
}

\author{
Budi Triyono $^{1}$, Yuli Prasetyo ${ }^{2}$, Hanifah N.K. ${ }^{1}$, R. Jasa Kusumo ${ }^{1}$, Basuki Winarno ${ }^{1}$, Aldanur I.R. ${ }^{1}$ \\ ${ }^{1}$ Prodi Teknik Listrik, Politeknik Negeri Madiun, Jl. Serayu No. 84, Madiun, 63133 \\ ${ }^{2}$ Prodi Perkeretaapian, Politeknik Negeri Madiun, Jl. Serayu No. 84, Madiun, 63133 \\ E-mail: buditriyono@pnm.ac.id
}

\begin{abstract}
Abstrak - Indonesia saat ini masuk kedalam kategori pandemi virus covid19. Banyak kota yang sudah terkena virus covid19 ini. Kota madiun juga sudah ada yang terkomfirmasi positif virus covid19. Oleh karena itu untuk mencegah penularan virus covid19 diperlukan upaya penanggulangan. Pondok pesantren merupakan tempat berkumpulnya para santri dari berbagai kota di Indonesia. Kalau di pondok pesantren tidak ada upaya pencegahan maka akan timbul claster baru virus covid19. Kegiatan pengabdian kepada masyarakat melalui program kemitraan bagi Pondok Pesantren Al Mujaddadiyah ini dititik beratkan pada pengembangan teknologi untuk mengatasi pencegahan virus covid19 di lingkungan pondok pesantren. Harapannya dengan pelatihan ini pengasuh pondok dan santri lebih dapat memahami protokol kesehatan yang diterapkan pada teknologi untuk mencegah penyebaran virus covid19 di lingkungan pondok.
\end{abstract}

Kata Kunci - Virus covid-19, disinfektan, Chamber, pondok pesantren

\begin{abstract}
Indonesia is currently included in the covid19 virus pandemic category. Many cities have been hit by the Covid19 virus. The city of Madiun has also been confirmed positive for the Covid19 virus. Therefore, to prevent the transmission of the Covid19 virus, prevention efforts are needed. Islamic boarding schools are a gathering place for students from various cities in Indonesia. If there are no prevention efforts at the Islamic boarding school, there will be a new covid19 virus cluster. Community service activities through the partnership program for the Al Mujaddadiyah Islamic Boarding School are focused on developing technology to overcome the prevention of the Covid19 virus in the Islamic boarding school environment. The hope is that with this training, boarding school caregivers and students can better understand the health protocols applied to technology to prevent the spread of the Covid19 virus in the cottage environment.
\end{abstract}

Keywords - Covid-19 virus, disinfectant, Chamber, Islamic boarding school

\section{PENDAHULUAN}

Indonesia saat ini mengalami masa pandemi covid19. Covid19 sudah menyebar luas diberbagai kota di Indonesia. Banyak kota - kota besar di Indonesia yang sudah menjadi zona merah penyebaran virus covid19. Pemerintah pusat atau pemerintah daerah sudah berupaya untuk mencegah penyebaran virus covid19. Berbagai cara memutus rantai penularan Covid-19 adalah menggunakan antiseptik untuk membasuh tangan dan bagian tubuh, Serta selalu cuci tangan selama 20 detik [1], [2]. Kemudian disinfektan yang disemprotkan atau diusapkan pada berbagai benda mati yang mungkin terpapar virus. Penggunaan antiseptic banyak digunakan dikalangan masyarakat daripada disinfektan. Kadar bahan aktif pada antiseptik jauh lebih rendah daripada disinfektan [3], [4].

Salah satu cara untuk mencegah penularan virus covid19 adalah penggunaan bilik disinfektan [5]. Bilik disinfektan ini adalah suatu alat yang berbentuk kotak yang dapat dilewati oleh manusia. Ketika manusia atau benda lain yang melewati bilik disinfektan maka akan otomatis terkena semprotan cairan disinfektan. Setelah manusia atau benda itu keluar dari bilik maka otomatis semprotan disinfektan akan berhenti. Bilik disinfektan ini sudah dilengkapi dengan sensor pendeteksi sehingga sudah dapat bekerja secara otomatis. Apabila cairan disinfektan sudah habis maka dapat diganti dengan cukup mudah.

Pencegahan virus covid19 juga dapat dilakukan dilingkungan pondok pesantren. Karena di lingkungan pondok selalu banyak orang dari berbagai daerah yang dikumpulkan jadi satu. Santri dari pondok pesantren juga banyak berasal dari berbagai kota di Indonesia. Saat ini santri dari berbagai kota sudah mulai masuk di asrama putra dan putri di pondok pesantren. Oleh karena itu perlu adanya upaya untuk pencegahan penyebaran virus covid 19 di lingkungan pondok pesantren. Salah satu yang kami akan terapkan adalah penerapan penggunaan bilik disinfektan (chamber). Penggunaan bilik disinfektan ini digunakan di asrama putra dan asrama putri pondok pesantren. 


\section{ANALISIS SITUASI}

Mitra dalam kegiatan PKM ini adalah Pondok pesantren Al Mujaddadiyah. Pondok pesantren ini berada di wilayah Demangan Kota Madiun. Hasil observasi, interview dan diskusi dengan mitra tentang masalah yang dihadapi mitra, maka dapat dirinci sebagai berikut:

a. Pondok Pesantren memiliki banyak santri dari berbagai kota di Indonesia.

b. Pondok Pesantren di kota lain sudah banyak terkena virus covid-19.

c. Pondok Pesantren belum memiliki peralatan protocol kesehatan untuk pencegahan virus covid-19.

d. Aktivitas di pondok yang sangat banyak serta terjadi banyaknya interaksi antar santri.

Dari rangkuman seluruh permasalahan tersebut, maka pokok persoalan yang dihadapi pondok pesantren adalah memerlukan teknologi untuk pencegahan virus covid-19. Untuk itulah rencana kegiatan yang diusulkan dalam pelaksanaan program PKM ini lebih menekankan pada usaha pembuatan peralatan protokol kesehatan serta pendampingan cara penggunaan alat. Hal ini diperlukan untuk meminimalisir penularan covid19 dikarenakan banyaknya santri di pondok pesantren seperti pada gambar 1 .

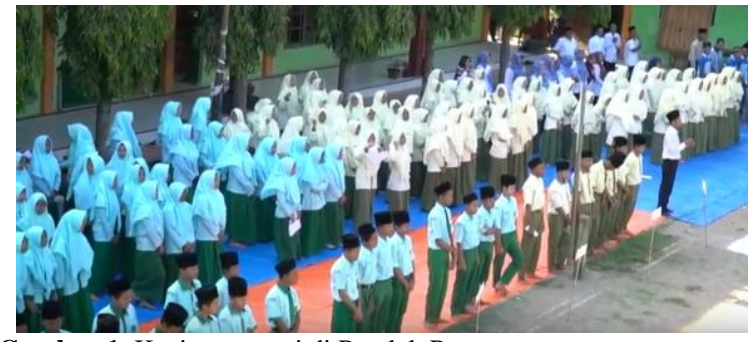

Gambar 1. Kegiatan santri di Pondok Pesantren

\section{METODE}

Kegiatan pengabdian kepada masyarakat dilakukan dengan beberapa tahap kegiatan. Tahapan kegiatan tersebut adalah tahapan mencari permasalahan, tahapan persiapan dan tahapan pelaksanaan. Pada tahapan mencari permasalahan adalah melakukan wawancara, observasi, dan konseling dengan kelompok tani berkaitan dengan permasalahan yang dihadapi. Pada tahapan persiapan melakukan pengadaan peralatan dan persiapan tempat dan sarana, dan pemberitahuan ke mitra tentang teknis pelaksanaan PKM. Pada tahapan pelaksanaan adalah pelaksanaan penerapan panel surya sesuai dengan jadwal yang telah ditetapkan.

Kegiatan pengabdian kepada masyarakat melalui program kemitraan bagi Pondok Pesantren Al Mujaddadiyah dititik beratkan pada pengembangan teknologi untuk pencegahan virus covid19 di lingkungan pondok pesantren. Harapannya dengan pelatihan ini pengasuh pondok dan santri lebih dapat memahami protokol kesehatan yang diterapkan pada teknologi untuk mencegah penyebaran virus covid 19 di lingkungan pondok

\section{HASIL DAN PEMBAHASAN}

Pelaksanaan PKM ini dimulai dengan pembuatan bilik disinfektan (Chamber). Pembuatan kerangka bilik disinfektan seperti pada gambar 2 . Setelah pembuatan kerangka adalah pembuatan sistem kontrol dan sensor. Pembuatan system control dan sensor ini digunakan untuk system otomatis pada bilik disinfektan. Sehingga apabila ada orang masuk ke bilik disinfektan maka sudah otomatis disinfektan chamber akan bekerja. Pembuatan alat bilik disinfektan yang sudah jadi seperti pada gambar 3 .

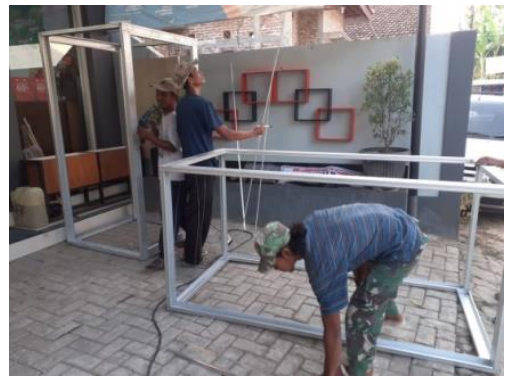

Gambar 2. Pembuatan Kerangka Bilik Disinfektan

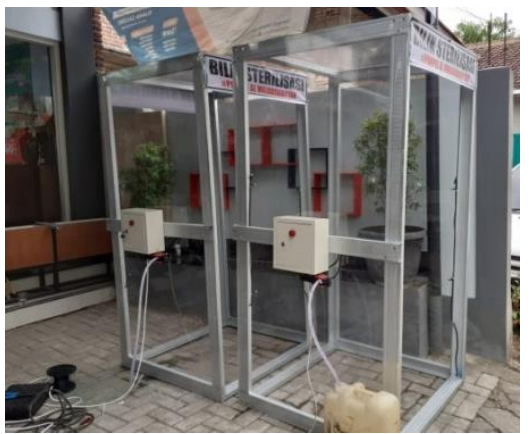

Gambar 3. Keseluruhan Alat Bilik Disinfektan

Setelah alat bilik disinfektan sudah selesai maka perlu penerapan bilik disinfektan di pondok pesantren. Pelaksanaan PKM ini di Pondok Pesantren Al Mujaddadiyah yang ada di desa Demangan Kota Madiun. Ada 2 bilik disinfektan yang digunakan untuk PKM kali ini. Penggunaan bilik disinfektan di lingkungan pondok pesantren terletak di asrama para santri. Penggunaan 1 bilik disinfektan di asrama putra dan penggunaan 1 bilik disinfektan di asrama putri. Sebelum diserahkan kepada pihak pondok pesantren, maka alat ini di uji coba dahulu oleh mahasiswa seperti pada gambar 4. Jadi cara kerja dari bilik disinfektan ini adalah jika ada orang yang masuk ke bilik maka akan otomatis di semprot. Penyemprotan ini akan berhenti jika orang telah melewati bilik disinfektan. Setelah berhasil di uji coba maka bilik disinfektan sudah dapat diterapkan di lingkungan pondok pesantren. Penggunaan bilik disinfektan di 
asrama putra seperti pada gambar 5. Penggunaan bilik disinfektan di asrama putra seperti pada gambar 6 .

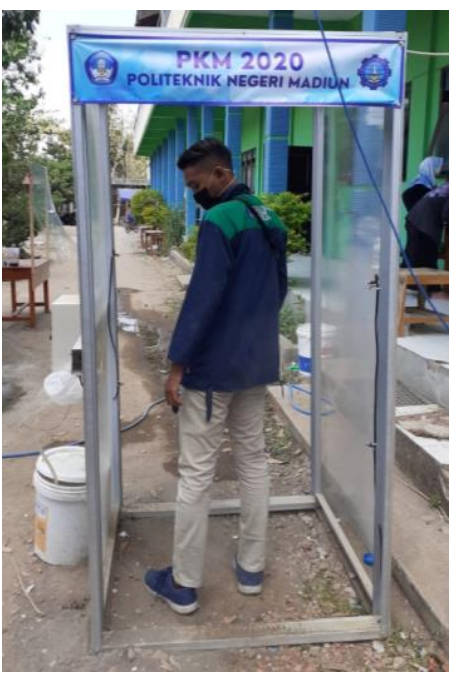

Gambar 4. Uji Coba Bilik Disinfektan

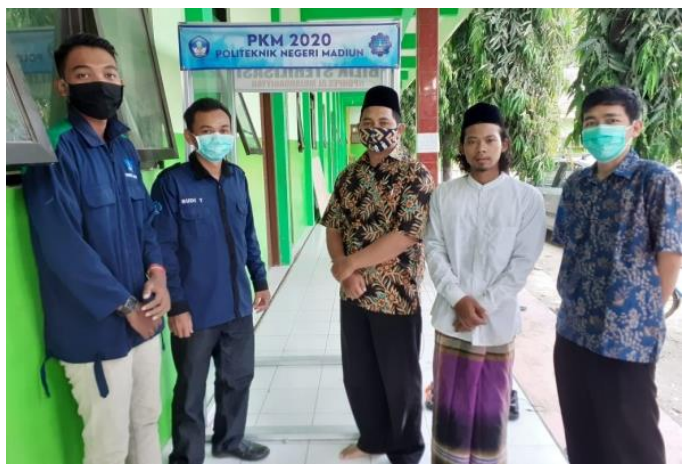

Gambar 5. Penggunaan bilik di asrama putra

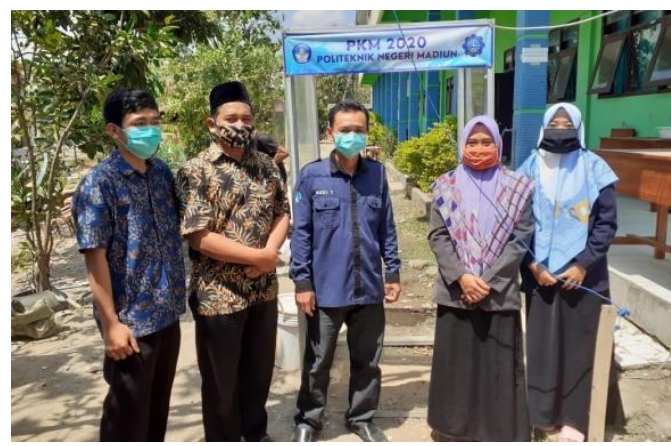

Gambar 6. Penggunaan bilik di asrama putri

Tabel 1 menjelaskan tentang kondisi mitra sebelum dan sesudah PKM. Di akhir pelaksanaan PKM ini dilakukan evaluasi antara tim pengusul dan mitra atas seluruh program yang telah dilaksanakan. Hasil evaluasi ini adalah pembinaan kepada mitra agar jika terjadi masalah atau kerusakan pada bilik disinfektan dapat segera diperbaiki sendiri oleh mitra. Semoga pandemi virus covid19 ini dapat segera berakhir dan dapat segera hilang dari Indonesia.
Tabel 1. Kondisi mitra sebelum dan sesudah pelaksanaan PKM

\begin{tabular}{ll}
\hline \multicolumn{1}{c}{ Sebelum PKM } & \multicolumn{1}{c}{ Setelah PKM } \\
\hline $\begin{array}{l}\text { Mitra belum memiliki } \\
\text { peralatan protokol kesehatan }\end{array}$ & $\begin{array}{l}\text { Mitra memiliki peralatan } \\
\text { protokol kesehatan yang } \\
\text { terletak di bagian depan } \\
\text { pondok dan bagian asrama } \\
\text { santri }\end{array}$ \\
$\begin{array}{l}\text { Mitra belum memiliki } \\
\text { pemahaman tentang } \\
\text { pentingnya pencegahan virus } \\
\text { covid-19. }\end{array}$ & $\begin{array}{l}\text { Mitra memiliki pemahaman } \\
\text { tentang tindakan pencegahan } \\
\text { virus covid-19 dan dapat } \\
\text { mengaplikasikan setiap hari }\end{array}$ \\
$\begin{array}{l}\text { Mitra belum memiliki } \\
\text { pengetahuan tentang } \\
\text { teknologi bilik disinfektan }\end{array}$ & $\begin{array}{l}\text { Meningkatnya kemampuan } \\
\text { dalam pengoperasian teknologi } \\
\text { bilik disinfektan }\end{array}$ \\
\hline
\end{tabular}

\section{KESIMPULAN}

Penggunaan bilik disinfektan dilingkungan pondok digunakan untuk meminimalkan penyebaran virus covid19 di pondok pesantren. Penggunaan bilik disinfektan ini membuat pondok pesantren terhindar dari virus covid19 dan tetap dapat melakukan kegiatan pondok sesuai protokol kesehatan.

\section{UCAPAN TERIMA KASIH}

Terimakasih kepada Politeknik Negeri Madiun yang sudah bersedia membantu pendanaan selama kegiatan Program Kemitraan Masyarakat tahun 2020 ini berlangsung.

\section{DAFTAR PUSTAKA}

[1] C. M. O. Muvianto and K. Yuniarto, Apr. 2020. Pemanfaatan Uv-C Chamber Sebagai Disinfektan Alat Pelindung Diri Untuk Pencegahan Penyebaran Virus Corona, Abdi Insani, vol. 7, no. 1 , pp. 87-92, doi: 10.29303/abdiinsani.v7i1.312.

[2] A. L. Larasati, D. Gozali, and C. Haribowo, May 2020, Penggunaan Desinfektan dan Antiseptik Pada Pencegahan Penularan Covid-19 di Masyarakat, Maj. Farmasetika, vol. 5, no. 3, doi: 10.24198/mfarmasetika.v5i3.27066.

[3] O. Setiani and T. Joko, 2015. Efektivitas Dosis Desinfektan Fenol Terhadap Angka Kuman Pada Lantai Ruang Rawat Inap Rsud Tugurejo Kota Semarang, J. Kesehat. Masy., vol. 3, p. 9.

[4] D. F. Sari, R. R. Parnaadji, A. Sumono, and J. Kalimantan, 2013. Pengaruh Teknik Desinfeksi dengan Berbagai Macam Larutan Desinfektan pada Hasil Cetakan Alginat terhadap Stabilitas Dimensional," vol. 1, no. 1, p. 6, 
Jati Emas (Jurnal Aplikasi Teknik dan Pengabdian Masyarakat)

Vol. 4 No. 2 Oktober 2020 - e. ISSN: 2550-0821

[5] A. N. Trisetiyanto, 2020. Rancang Bangun Alat Penyemprot Disenfektan Otomatis Untuk Mencegah Penyebaran Virus Corona," Journal of Informatic Education, vol. 3 no 1, p. 45-51 